\title{
PENGARUH EFIKASI DIRI DAN KEPUASAN KERJA GURU \\ TERHADAP KOMITMEN ORGANISASI PADA SPK SD DAN SMP DI KECAMATAN KALIDERES DAN CENGKARENG PROVINSI JAKARTA
}

\author{
Boem Kim Fung
}

\author{
Amos Neolaka \\ amos_neolaka@yahoo.com \\ Hotmaulina Sihotang \\ hotmaulina.sihotang@uki.ac.id
}

\begin{abstract}
Abstrak
Boen Kim Fung, Pengaruh Efikasi Diri dan Kepuasan Kerja Guru terhadap Komitmen Organisasi SPK SD dan SMP di Kecamatan Cengkareng dan Kalideres, Jakarta.

Penelitian ini bertujuan untuk menguji pengaruh efikasi diri dan kepuasan kerja terhadap komitmen organisasi bagi para guru. Populasi dalam penelitian ini adalah para guru lokal SPK SD dan SMP di kecamatan Cengkareng dan Kalideres yang berjumlah 203 orang. Penulis menggunakan tabel Krejcie dan Morgan untuk menentukan jumlah sampel. Sampel yang diambil berjumlah 118 sampel. Metode penelitian yang digunakan adalah metode penelitian kuantitatif dengan teknik deskriptif dan korelasi. Data yang didapat dari kuesioner diolah dengan menggunakan Pearson Product Moment. Hasil penelitian menunjukkan bahwa ada pengaruh langsung positif efikasi diri guru terhadap komitmen organisasi. Kepuasan kerja guru juga berpengaruh langsung positif terhadap komitmen organisasi. Variabel efikasi diri dan kepuasan kerja guru secara bersama sama berpengaruh positif terhadap komitmen organisasi.
\end{abstract}

Kata kunci: efikasi diri, kepuasan kerja, dan komitmen organisasi. 
Pengaruh Efikasi Diri dan Kepuasan Kerja Guru terhadap Komitmen Organisasi SPK SD dan SMP di Kecamatan Cengkareng dan Kalideres, Jakarta.

\begin{abstract}
The purpose of this study was to examine the effect of self-efficacy and job satisfaction on organizational commitment for primary and junior high school teachers. The population in this study were 203 primary and junior high school SPK local teachers in Cengkarng and Kalideres sub-districts. Krejcie \& Morgan table was used to determine the number of samples. The study was conducted using quantitative research design and correlation model. The sample of this study was 118 teachers from 4 SPK schools. The results showed that there was a positive direct effect of teachers' self-efficacy on organizational commitment. Teacher job satisfaction had also direct positive effect on organizational commitment. Both independent variables of self-efficacy and job satisfaction simultaneously had a positive effect on organizational commitment.
\end{abstract}

Keywords: Self Efficacy, Job Satisfaction, Organizational Commitment. 


\section{A. PENDAHULUAN}

Komitmen adalah hal yang wajib dimiliki para anggota organisasi agar dapat tercapainya apa yang menjadi tujuan organisasi. Sebagai anggota dari suatu organisasi harus mempunyai komitmen terhadap organisasinya sehingga anggota tersebut akan menjadi semakin bertanggung jawab atas pekerjaannya. Komitmen seseorang pada organisasinya ditunjukkan dengan memberikan perhatian,tenaga dan waktu yang lebih untuk pekerjaannya, sehingga tujuan organisasi tersebut akan dapat dicapai dengan baik. Jika anggota mempunyai komitmen pada organisasinya maka tentunya ia akan berusaha mempertahankan keanggotaannya.

Sekolah merupakan organisasi pembelajaran, sebab itu komitmen organisasi sangat diperlukan dalam sekolah. Salah satu kunci pelaksanaan pendidikan yang bermutu adalah komitmen organisasi dari para pendidik. Sekolah tentunya menginginkan semua pendidik yang terlibat di dalamnya mempunyai komitmen yang tinggi dalam bekerja, karena jika semua pendidik mempunyai komitmen tinggi pada organisasi sekolah maka para pendidik tersebut akan menghargai nilai nilai yang ada di tempat mengajarnya dan juga akan bersikap lebih professional. Pendidik merupakan bagian dari organisasi sekolah dan merupakan ujung tombak keberhasilan suatu sekolah. Pendidik mempunyai beban dan komitmen yang besar dalam membentuk generasi muda supaya menjadi satu angkatan penerus bangsa yang berguna bagi kemajuan bangsa dan negara.

Kemampuan dari para pendidik, komitmen, kepuasan, dan motivasi adalah faktor faktor penting yang akan mempengaruhi para guru di dalam membentuk murid muridnya. Oleh karena itu pendidik adalah sumber yang paling penting di dalam sekolah. Pendidik adalah agen perubahan dan kunci untuk perubahan yang dibutuhkan di dalam sekolah. Di dalam era globalisasi ini sekolah perlu memperhatikan serta menjaga para pendidik agar mereka dapat mengembangkan kemampuan dirinya dan mempunyai rasa puas terhadap pekerjaannya. Jika sekolah ingin mempertahankan daya saing sekolah tersebut maka sekolah harus mencari tahu apa saja yang mempengaruhi komitmen organisasi dan bagaimana meningkatkan komitmen organisasi. Untuk dapat membentuk komitmen organisasi ini diperlukan suatu proses yang cukup lama dan juga banyak faktor yang ikut berperan. Di antara banyak faktor tersebut mungkin saja efikasi diri dan kepuasan kerja pendidik mempengaruhi komitmen organisasi pendidik.

Berdasarkan yang sudah dijelaskan di atas penulis melaksanakan suatu proses penelitian yang meneliti mengenai pengaruh efikasi diri dan kepuasan kerja guru terhadap komitmen organisasi.

\section{B. KAJIAN LITERATUR}


Pengaruh Efikasi Diri dan Kepuasan Kerja Guru terhadap Komitmen Organisasi SPK SD dan SMP di Kecamatan Cengkareng dan Kalideres, Jakarta.

\section{Komitmen}

Porter et al (1974) menggambarkan komitmen organisasi sebagai sebuah keterikatan pada organisasi. Seorang karyawan tetap tinggal di dalam organisasi di mana dia bekerja dan melakukan upaya ekstra untuk organisasi nya karena ia merasa bahwa norma norma dan tujuan dirinya sendiri sama dengan organissi tersebut. 
Mowday,Porter,dan Steers(1982) mengatakan bahwa komitmen organisasi adalah tingkah laku yang berkaitan dengan proses di mana individu menjadi terkunci dalam organisasi tertentu dan bagaimana mereka berurusan dengan masalah ini. Sedangkan menurut Bateman dan Strasser (1984) menyatakan bahwa definisi dari komitmen organisasi adalah multidimensial,yang melibatkan loyalitas karyawan kepada organisasi, kesediaan untuk mengerahkan upaya atas nama organisasi,selalu disesuaikan dengan tujuan dan nilai organisasi, dan keinginan untuk mempertahankan keanggotaannya. Menurut Robbins (1998) komitmen organisasi adalah sejauh mana seorang karyawan mengidentifikasikan dirinya dengan organisasi tertentu dan tujuannya,dan ingin mempertahankan keanggotaannya dalam organisasi tersebut.

Sedangkan menurut Best (1994) individu yang berkomitmen memberlakukan perilaku spesifik karena keyakinan bahwa itu benar secara moral daripada bermanfaat secara pribadi. Pengertian komitmen organisasi menurut Luthans (2006) kemauan kuat untuk tetap berda dalam organisasi tertentu serta keinginannya sesuai dengan harapan organisasi serta menerima nilai dan tujuan organisasi. Komitmen kerja yang tinggi yang dimiliki oleh karyawan akan selalu mendorongnya untuk mencapai apa yang menjadi tujuan dari organisasi tempatnya bekerja. Misalnya seorang individu telah bekerja di sekolah tertentu selama lima tahun,sekolah telah memberikan pelatihan pelatihan dan individu tersebut juga menikmati pekerjaannya di sekolah tersebut.Gaji yang diberikan oleh sekolah tersebut juga cukup kompetitif. Ketika individu ini sedang mengikuti suatu pelatihan tiba tiba pimpinan dari sekolah lain yang juga sedang mengikuti pelatihan menawarkan individu ini untuk pindah ke sekolah lain.Apa kira kira yang dipikirkan oleh individu itu? Kalau individu itu mempunyai komitmen organisasi yang tinggi tentu ia akan menolak tawaran itu. Jika pendidik itu mempunyai komitmen organisasi yang tinggi pada umumnya pendidik itu mempunyai perasaan yang positif terhadap salah satu aspek dari pekerjaannya misalnya rekan kerja, pimpinan atau pekerjaan yang dikerjakannya. Meyer dan Allen $(1997,106)$ menggunakan model tiga dimensi untuk mengkonseptualisasikan komitmen organisasi yaitu: a) komitmen afektif. Seorang pendidik yang mempunyai komitmen afektif mempunyai kedekatan emosional yang erat dengan tempat dia mengajar. Karena komitmen afektif menggambarkan hubungan emosional terhadap organisasi, maka hanya hubungan dengan rekan kerja dan atasan yang mempengaruhinya. Karena itu, kita dapat lebih memahami tentang komitmen afektif jika kita memperhatikan pada suatu ikatan yang mengikat antara sesama rekan kerja. Guru yang mempunyai komitmen afektif tinggi tetap bergabung dengan sekolah di mana dia bekerja karena keinginan menjadi bagian dari sekolah tersebut. Komitmen afektif memberikan pengaruh yang sangat besar secara langsung apakah orang 
tersebut ingin tetap tinggal atau ke luar dari tempatnya bekerja. Jika seseorang memiliki komitmen afektif tinggi, maka hamper tidak ada keinginannya untuk mengundurkan diri dari tempatnya bekerja. Dedikasi dan loyalitas yang dimiliki individu terhadap organisasi ditentukan oleh ikatan emosional individu tersebut kepada organisasi (Rhoades dkk, 2001). Hartmann dan Bambacas (2000) mengartikan komitmen afektif adalah seseorang yang telah memiliki perasaan terikat dengan organisasi termasuk di dalamnya hubungan dengan sesama rekan kerja, susunan organisasi, lamanya bekerja, termasuk di dalamnya honor yang diterima, fungsi dan kapasitas serta berbagai keterampilan di dalam organisasi. Buchanan (dalam Allen dan Meyer, 1990) mendeskripsikan komitmen afektif adalah seorang karyawan karena merasa terikat secara psikologis dengan organisasi maka dia akan terlibat di dalam mencapai nilai dan tujuan dari organisasi tersebut. Jadi jika guru menyukai pekerjaannya,merasa senang dan merasa puas terhadap pekerjaannya serta mempunyai ikatan emosional dengan atasan atau sesama guru di sekolahnyanmaka berarti guru tersebut mempunyai komitmen afektif yang tinggi.b) Komitmen kelanjutan.Komitmen ini terjadi ketika guru mempertimbangkan apakah dia tetap harus tinggal atau ke luar dari tempatnya dia bekerja. Guru tersebut mungkin merasa perlu untuk tetap tinggal di sekolah itu karena jika meninggalkan sekolah tersebut dia kan mengalami kerugian yang lebih besar daripada manfaat yang diperoleh di sekolah yang baru. Kerugian ini bisa misalnya kehilangan uang (honor,tunjangan,bonus), jabatan ( kehilangan senioritas atau kedudukan yang telah dijalani sekian lama) atau hubungan dengan sesama (kehilangan pertemanan). Kerugian ini akan bertambah dengan meningkatnya usia dan pengalaman. Guru akan cenderung memiliki komitmen kelanjutan jika guru tersebut sudah mapan atau mendapatkan promosi di sekolah tempat dia bekerja. Pada umumnya komitmen ini bisa terbentuk karena semakin lama seorang guru bekerja di suatu sekolah maka guru tersebut takut akan sesuatu yang hilang yang sudah guru tersebut dapatkan dan tanamkan di dalam sekolah tersebut.

\section{Komitmen Normatif}

Komitmen normatif adalah komitmen guru terhadap sekolahnya ketika mereka merasa bahwa mereka harus terus bekerja di sana. Jadi guru tersebut merasa mempunyai kewajiban untuk bekerja di sekolah tersebut karena semua hal yang telah sekolah lakukan untuk dirinya. Guru tersebut kuatir jika mereka mengundurkan diri maka rekan kerja mereka akan mempunyai pikiran yang buruk tentang mereka.

Jika Kepala Sekolah dapat memilih jenis komitmen yang ingin mereka tanamkan pada guru guru mereka,maka kepala sekolah akan memilih komitmen afektif.Jika Kepala Sekolah mengatakan'Dia berkomitmen 
"atau "Dia setia",maka Kepala Sekolah itu biasanya metujuk pada perilaku dari komitmen afektif.

Berdasarkan keterangan di atas maka komitmen organisasi disintesiskan sebagai tingkah laku setia individu yang merupakan anggota suatu organisasi terhadap organisasi tersebut demi tercapainya visi,misi ,dan tujuan organisasi. Dimensi dari komitmen organisasi adalah kemauan yang sungguh sungguh untuk tetap berada dalam organisasi tersebut, bekerja dengan sungguh sumgguh dan mempunyai kepercayaan pada nilai nilai dan tujuan organisasi. Seorang individu dapat mempunyai komitmen organisasi karena memang mereka ingin,mereka harus atau karena mereka perlu.

\section{Efikasi Diri}

Menurut Bandura (1986) efikasi diri adalah rasa yakin yang dimiliki seseorang di mana orang tersebut yakin bahwa dia sanggup menyelesaikan tugas yang diberikan. Sedangkan menurut Baron (1996) orang yang mempunyai efikasi diri adalah orang yang punya perasaan yakin akan kompetensinya dalam melakukan hal hal yang diinginkan.Menurut Feist dan Feist (1998) efikasi diri yaitu seseorang yang yakin bahwa dirinya mampu mencapai hasil tertentu dalam melaksanakan suatu kegiatan atau tugas. Efikasi diri menurut Santrock (2007) yaitu orang yang percaya akan kompetensinya untuk mengatasi berbagai kondisi dan yakin akan mendatangkan keuntungan.Ghufran dan Risnawita(2012) mendeskripsikan efikasi diri sebagai suatu sudut pandang tentang kemampuan diri sendiri yang berdampak dalam kehidupan diri kita sendiri. Keyakinan diri yang tinggi dari seorang guru dapat dilihat dari partisipasinya dalam menyelesaikan tugasnya sedangkan guru dengan efikasi diri yang rendah akan menjadi semacam penghambat bagi tercapainya tujuan dari proses belajar mengajar di tempatnya mengajar. Guru yang mempunyai efikasi diri yang tinggi selalu mencoba yang terbaik untuk menyelesaikan tugas dan juga berusaha mengatasi dan mengalahkan kesulitan yang mereka hadapi. Menurut Bandura ada 4 hal yang mempengaruhi efikasi diri yaitu penguasaan pengalaman,pemodelan sosial,persuasi sosial,dan respon psikologis. Penguasaan pengalaman adalah semakin kita berhasil melakukan tugas maka semakin kuatlah perasaan kita tentang kemampuan diri kita. Penguasaan pengalaman ini lah yang paling mempengaruhi efikasi diri seseorang.Pemodelan sosial adalah jika kita melihat orang lain berhasil menyelesaikan tugas maka ini akan membantu kita membangun efikasi diri kita sedangkan pemodelan sosial adalh jika seseorang memuji kita atau mengatakan yang positif tentang kita maka ini dapat membantu kita untuk mengatasi keraguan sehingga kita akan memberikan usaha kita yang terbaik untuk menyelesaikan tugas kita. Perasaan kita mengenai kemampuan kita untuk bethasil juga dapat dipengaruhi oleh keadaan fisik 
maka ini yang disebut dengan respons psikologis.

Menurut Gibsaon (2003.155) efikasi diri memiliki tiga dimensi yaitu besaran, kekuatan,dan generalitas. Besaran artinya seorang individu yang merasa yakin bahwa dia dapat mengatasi tingkat kesulitan tertentu. Kekuatan adalah individu tersebut memiliki keyakinan dapat menyelesaikan suatu pekerjaan pada suatu tingkat kesukaran tertentu. Sedangkan generalitas merujuk pada suatu cita cita yang berlangsung secara umum dalam keadaan apa pun.Sedangkan menurut Bandura(2002) ada beberapa dimensi dari efikasi diri yaitu level,kekuatan,dan umum.level adalah orang yang memiliki rasa yakin yang tinggi akan kemampuannya dalam menuntaskan pekerjaan dan mengatasi berbagai masalah sedangkan kekuatan adalah orang yang merasa yakin akan kemampuannya dan dia akan berjuang sekuatnya untuk merampungkan tugas tugsnya dan umum adalah bagaimana caranya seeeorang dapat menggunakan kemampuan dalam dirinya sendiri untuk mengatasi berbagai situasi. Dari beberapa penjelasan tentang efikasi diri di atas maka pengertian efikasi diri dapat disintesiskan perasaan yakin individu akan kompetensinya di dalam menyelesaikan berbagai tugas dan kewajiban yang diserahkan kepadanya serta kemampuan individu di dalam menghadapi berbagai situasi.

\section{Kepuasan Kerja}

Kepuasan kerja adalah perasaan puas pekerja atas semua aspek di tempat bekerja mereka. Perasaan senang atau puas itu bisa didapat dari berbagai aspek pekerjaan itu. Kepuasan kerja berhubungan erat dengan sikap dan tingkah laku karyawan pada tempatnya bekerja. (Davis et al., 1985,109). Pengertian kepuasan kerja menurut Robbins (1996) yaitu bagaimana seorang individu bersikap atas pekerjaannya. Di dalam melakukan pekerjaan kita berhubungan dengan berbagai peraturan selain kita juga harus menjalin hubungan dengan sesama rekan kerja dan atasan. Jika seseorang menunjukkan sifat yang konstruktif terhadap pekerjaannya maka itu menujukkan bahwa dia puas akan pekerjaannya. diidentikkan dengan hal hal yang berhubungan Pengertian kepuasan kerja menurut Wexley dan Yuki (2003) adalah sudut pandang seseorang terhadap pekerjaannya. Kepuasan kerja dijelaskan juga sampai di mana karyawan merasa senang dengan honor yang didapatnya dari tempatnya berkarya, terutama dalam hal motivasi intrinsik (Statt, 2004,78).

Puas terhadap pekerjaan berhubungan dengan perasaan serta yang dimiliki karyawan tentang pekerjaan mereka. Jika seseorang bersikap positif terhadap pekerjaannya maka dapat dikatakan kalau dia puas terhadap pekerjaannya. Jika dia bersikap negatif serta tidak menguntungkan terhadap pekerjaannya maka mengindikasikan ketidakpuasan kerja (Armstrong, 2006,264).

Menurut Luthans (2006) kepuasan kerja adalah jika karyawan merasa 
bahwa pekerjaannya memberikan sesuatu yang berdampak baik dan penting bagi mereka.

Ada beberapa faktor yang mempengaruhi kepuasan kerja. Faktor-faktor ini telah disusun menurut dua dimensi, yaitu, faktor ekstrinsik dan intrinsik. Sumber kepuasan kerja ekstrinsik ditentukan oleh kondisi yang berada di luar kendali karyawan (Atchison, 2005). Faktor ekstrinsik meliputi aspek-aspek seperti upah, peluang promosi, rekan kerja, dan pengawasan. Faktor intrinsik termasuk kepribadian, pendidikan, intelegensi dan kompetensi,umur, dan apakah lajang atau menikah (Mullins, 2005). Tercatat bahwa faktor ekstrinsik dan intrinsik sering bekerja bersama untuk mempengaruhi kepuasan kerja.

Ketika berbicara tentang kepuasan kerja, sebagai persepsi yang terdiri dari berbagai dimensi, ini harus dijelaskan dimensi pekerjaan mana yang membuat karyawan memiliki kepuasan kerja. Herzberg (1987) mengemukakan dua jenis faktor yang berkontribusi terhadap kepuasan kerja dan ketidakpuasan kerja. Yang pertama adalah motivator (faktor intrinsik): pengakuan, pertumbuhan pribadi, pekerjaan itu sendiri, peluang untuk promosi, prestasi. Faktor kebersihan (faktor ekstrinsik) memastikan bahwa karyawan melakukan tugas mereka pada tingkat minimum. Ini adalah: pengawasan, keamanan, kebijakan organisasi, situasi dalam pekerjaan, honor, hubungan sesama teman kerja dan penyelia dan status dikaitkan dengan kepuasan kerja. Sementara adanya faktor ekstrinsik tidak menjamin kepuasan kerja, ketidakhadiran mereka dapat menyebabkan ketidakpuasan kerja karyawan (Herzberg, 1987).

Menurut yang sudah dijelaskan di atas maka penulis dapat mensintesiskan kepuasan kerja adalah seorang pekerja yang merasa bahwa apa yang diterimanya dari tempatnya bekerja sesuai yang diharapkannya. Dimensi dari kepuasan kerja adalah mempunyai moral kerja yang baik dan positif, berperilaku yang menunjukkan nilai nilai ketaatan dan disiplin yang tinggi serta akan berprestasi dalam pekerjaannya.

\section{HIPOTESIS PENELITIAN}

- H1 Efikasi diri guru berpengaruh positif terhadap komitmen organisasi

- H2 Kepuasan kerja guru berpengaruh positif terhadap komitmen organisasi

- H3 Efikasi diri dan kepuasan kerja guru secara bersama sama berpengaruh positif terhadap komitmen organisasi.

\section{MODEL PENELITIAN}

\section{Populasi dan Sampel}

Populasi dalam penelitian ini adalah semua guru lokal yang bekerja di SPK SD dan SMP di kecamatan Cengkareng dan Kalideres yang berjumlah 203 orang. Dari 203 orang ini penulis mengambil 30 orang untuk uji validitas dan 
realibilitas. Kemudian dari 173 orang penulis mengambil 118 orang sampel berdasarkan tabel Krejcie dan Morgan. Penulis membagikan kuesioner yang berisikan butir pernyataan dari 3 variabel. Semua pernyataan diukur pada skala liekert lima poin.

\section{E. METODE ANALISIS DATA}

\section{Uji Validitas}

Tingkat kevalidan dari suatu instrumen ditunjukkan oleh suatu ukuran yang disebut validitas. Pengujian ini dihitung berdasarkan Statistical Package for the Social Science (SPSS) dan Microsoft Office Excel. Untuk menentukan kevalidan suatu instrument adalah nilai $r$ tabel <dari $r$ hitung jika nilai $r$ hitung lebih kecil dari $r$ tabel dengan taraf signifikan 0,05 maka instrumen dinyatakan tidak valid.

\begin{tabular}{|l|l|l|l|}
\hline \multicolumn{1}{|c|}{ Variabel } & \multicolumn{1}{|c|}{$\begin{array}{c}\text { Jumlah soal } \\
\text { sebelum uji coba }\end{array}$} & $\begin{array}{c}\text { Jumlah soal } \\
\text { sesudah uji coba }\end{array}$ & $\begin{array}{c}\text { Persen valid } \\
(\%)\end{array}$ \\
\hline Efikasi Diri & 36 & 28 & 77.7 \\
\hline Kepuasan Kerja & 27 & 26 & 96 \\
\hline $\begin{array}{l}\text { Komitmen } \\
\text { Organisasi }\end{array}$ & 16 & 12 & 75 \\
\hline
\end{tabular}

\section{Uji Realibilitas}

Penulis melakukan uji realibilitas agar dapat mengetahui apakah penelitian ini dapat diandalkan atau tidak. Penelitian dapat diandalkan bila memberikan hasil yang konsisten untuk pengukuran yang sama. Jadi diharapkan melalui uji realibilitas ini penulis mengetahui instrumen instrumen dalam kuesioner adalah konsisten apabila digunakan untuk mengukur gejala yang sama di lain tempat. Uji realibiltas ini juga dihitung berdasarkan Statistical Package for the Social Science (SPSS) dengan menggunakan cronbach's alpha dan Microsoft Office Excel.

Hasil uji reliabilitas dari 66 butir soal yang valid, yaitu memperoleh nilai Cronbach's Alpha 0,935 maka dinyatakan 66 butir soal tersebut memiliki nilai reliabilitas tinggi.

\section{Uji Persyaratan Analisis}

\section{Uji Normalitas}

Penulis menggunakan uji normalitas Kolmogorov Smirnov untuk mengetahui bahwa sampel yang digunakan dalam penelitian berdistribusi normal. Ketentuan dalam uji normalitas adalah distribusi data disebut normal jika nilai signifikan $>0,05$. Dalam uji normalitas dari ke tiga variabel ternyata semua data berdistribusi normal. 


\section{Tests of Normality}

\begin{tabular}{|c|c|c|c|c|c|c|}
\hline & \multicolumn{3}{|c|}{ Kolmogorov-Smirnov ${ }^{\mathrm{a}}$} & \multicolumn{3}{|c|}{ Shapiro-Wilk } \\
\hline & Statistic & df & Sig. & Statistic & $\mathrm{df}$ & Sig. \\
\hline Efikasi Diri & 0,066 & 118 & $200^{*}$ & 0,988 & 118 & 0,373 \\
\hline
\end{tabular}

Tests of Normality

\begin{tabular}{|c|c|c|c|c|c|c|}
\hline & \multicolumn{3}{|c|}{ Kolmogorov-Smirnov ${ }^{\mathrm{a}}$} & \multicolumn{3}{|c|}{ Shapiro-Wilk } \\
\hline & Statistic & $\mathrm{df}$ & Sig. & Statistic & $\mathrm{df}$ & Sig. \\
\hline $\begin{array}{l}\text { Komitmen } \\
\text { Organisasi }\end{array}$ & 0,076 & 118 & 0,088 & 0,986 & 118 & 0,272 \\
\hline
\end{tabular}

a. Lilliefors Significance Correction

\section{Tests of Normality}

\begin{tabular}{|c|c|c|c|c|c|c|} 
& \multicolumn{3}{c}{ Kolmogorov-Smirnov } & \multicolumn{3}{c}{ Shapiro-Wilk } \\
& Statistic & df & Sig. & Statistic & df & Sig. \\
\hline Efikasi Diri & 0,066 & 118 &, $200^{*}$ & 0,988 & 118 & 0,373 \\
\hline
\end{tabular}

*. This is a lower bound of the true significance.

a. Lilliefors Significance Correction

\section{Uji Linearitas}

Uji terakhir yang diperlukan sebelum dilakukan analisis adalah uji linearitas. Uji ini bertujuan untuk mengetahui apakah ada hubungan yang linear dan signifikan antara dua variabel. Jika ada hubungan yang linear antara variabel independent dan dependent maka terdapat korelasi yang baik. Dasar pengambilan keputusan untuk uji linearitas ini adalah jika signifikan > 0,05 dan jika nilai Ftabel < F hitung maka ada hubungan liniear secara signifikan antara variabel independent dan dependent. Hasil uji linearitas variabel efikasi diri atas komitmen organisasi adalh nilai Signifikan adalah 0,566 dan nilai $\mathrm{F}$ hitung adalah 0,950 maka ada hubungan linear secara signifikan antara variabel efikasi diri dengan variabel komitmen organisasi.Demikian juga ada hubungan linear secara signifikan antara variabel kepuasan kerja terhadap variabel komitmen organisasi karena hasil dari uji linearitas nya adalah signifikan nya 0,409 dan nilai F hitungnya 1.058. 


\begin{tabular}{|c|c|c|c|c|c|c|c|}
\hline \multicolumn{8}{|c|}{ ANOVA Table } \\
\hline & & & $\begin{array}{l}\text { Sum of } \\
\text { Squares }\end{array}$ & df & $\begin{array}{c}\text { Mean } \\
\text { Squar } \\
\text { e }\end{array}$ & $\mathrm{F}$ & Sig. \\
\hline \multirow{5}{*}{$\begin{array}{l}\text { KOmitmen } \\
\text { Organisasi } \\
* \text { Efikasi } \\
\text { Diri }\end{array}$} & \multirow{3}{*}{$\begin{array}{l}\text { Between } \\
\text { Groups }\end{array}$} & (Combined) & 9,895 & 45 & 0,220 & 1,270 & 0,180 \\
\hline & & Linearity & 2,656 & 1 & 2,656 & 15,339 & 0,000 \\
\hline & & $\begin{array}{l}\text { Deviation } \\
\text { from } \\
\text { Linearity }\end{array}$ & 7,239 & 44 & 0,165 & 0,950 & 0,566 \\
\hline & \multicolumn{2}{|c|}{ Within Groups } & 12,466 & 72 & 0,173 & & \\
\hline & \multicolumn{2}{|l|}{ Total } & 22,361 & 117 & & & \\
\hline
\end{tabular}

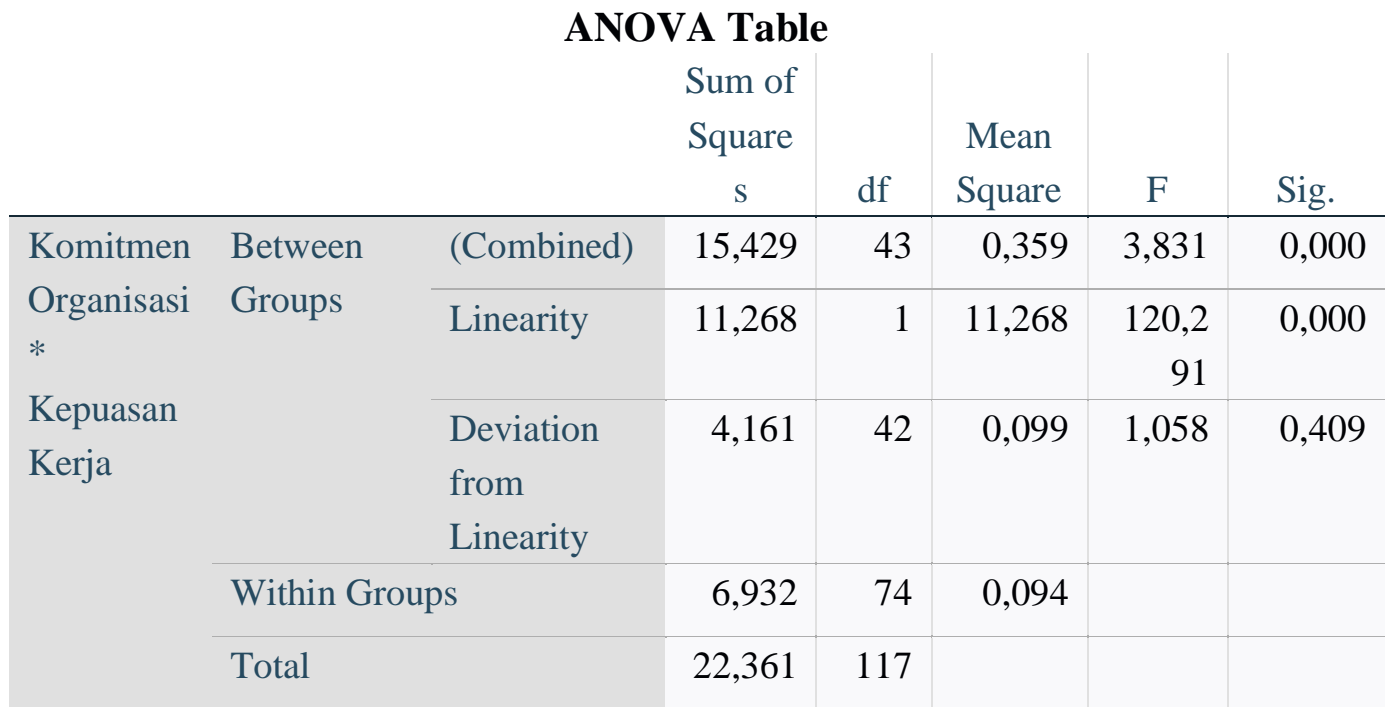

\section{Uji Analisis Korelasi}

Uji analisis korelasi untuk mengetahui kedekatan hubungan antar variabel yang dinyatakan dengan nilai koefisien korelasi. Hubungan antara variabel tersebut dapat bersifat positif dan negative. Penulis menggunakan rumus uji analisis korelasi Bivariate Pearson. Dasar pengambilan keputusan dalamanalisis korelasi Bivariate Pearson ini yaitu jika nilai Sig (2-tailed) $<0,05$, nilai $\mathrm{r}$ hitung $>\mathrm{r}$ tabel. dari hasil uji analisis korelasi ini diketahui bahwa terdapat korelasi yang signifikan antara efikasi diri dengan variabel kepuasan kerja karena nilai signifikannya adalah 0,000 demikian juga hubungan antar efikasi diri dengan komitmen organisasi nilai signifikannya 0,000 .

Antar variabel kepuasan kerja dengan variabel komitmen organisasi juga ada korelasiyang signifikan karena nilainsignifikannya 0,000 . 


\section{Correlations}

\begin{tabular}{|c|c|c|c|c|}
\hline \\
\hline & & Efikasi Diri & Kepuasan Kerja & $\begin{array}{l}\text { Komitmen } \\
\text { Organisasi }\end{array}$ \\
\hline \multirow[t]{3}{*}{ Efikasi Diri } & Pearson Correlation & 1 &, $623^{* * *}$ &, $345^{* *}$ \\
\hline & Sig. (2-tailed) & &, 000 & ,000 \\
\hline & $\mathrm{N}$ & 118 & 118 & 118 \\
\hline \multirow[t]{3}{*}{ Kepuasan Kerja } & Pearson Correlation &, $623^{* *}$ & 1 &, $710^{* *}$ \\
\hline & Sig. (2-tailed) & ,000 & & ,000 \\
\hline & $\mathrm{N}$ & 118 & 118 & 118 \\
\hline \multirow[t]{3}{*}{ Komitmen Organisasi } & Pearson Correlation &, $345^{* *}$ &, $710^{* *}$ & 1 \\
\hline & Sig. (2-tailed) & ,000 &, 000 & \\
\hline & $\mathrm{N}$ & 118 & 118 & 118 \\
\hline
\end{tabular}

**. Correlation is significant at the 0.01 level (2-tailed).

\section{Uji Hipotesis dan Hasil Penelitian}

1. Hipotesis pertama diuji menggunakan analisis regresi linier sederhana dengan Software SPSS. Dasar pengambilan keputusan dalam analisis regresi adalah dengan melihat nilai signifikan jika nilai signifikan < dari probabilitas $(0,05)$ atau jika nilai $\mathrm{t}$ hitung $>\mathrm{t}$ tabel maka dapat disimpulkan $\mathrm{H}_{0}$ ditolak.

Dari hasil perhitungan dengan SPSS nilai signifikan 0,000 (lebih kecil dari 0,05) dan t hitung 3,954 (lebih besar dari t tabel 1,98063) maka hasil penelitian adalah Efikasi diri berpengaruh positif terhadap Komitmen Organisasi.

\section{Coefficients $^{\mathrm{a}}$}

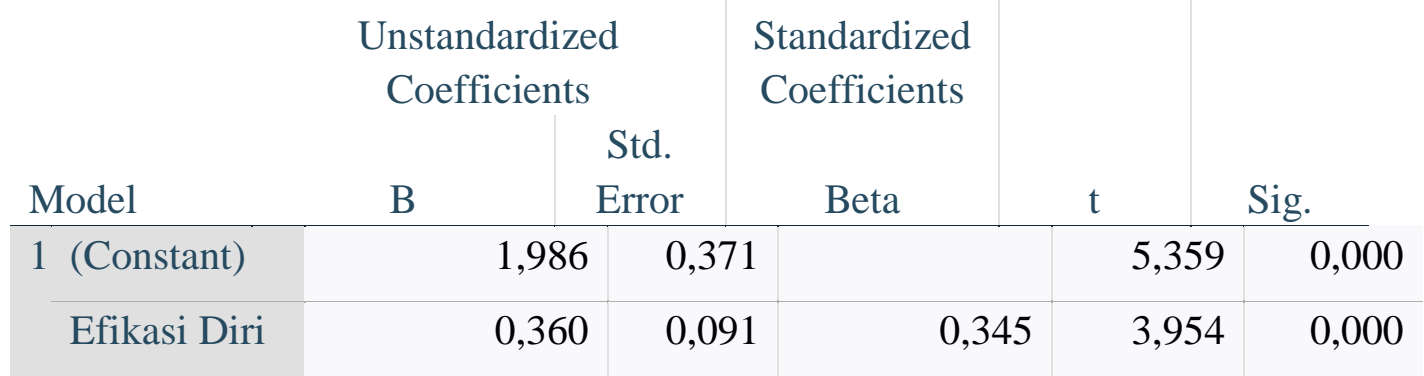

a. Dependent Variable: Komitmen Organisasi

2. Hipotesis kedua diuji menggunakan uji analisis regresi linier sederhana dengan menggunakan Software SPSS. Dasar pengambilan keputusan dalam analisis regresi adalah dengan melihat nilai signifikan jika nilai signifikan < dari probabilitas $(0,05)$ atau jika nilai t hitung $>\mathrm{t}$ tabel maka dapat disimpulkan $\mathrm{H}_{0}$ ditolak.

Dari hasil perhitungan dengan SPSS nilai signifikan 0,000 (lebih kecil dari 0,05) dan thitung 10,855 (lebih besar dari t tabel 1,98063) maka hasil penelitian Kepuasan kerja berpengaruh positif terhadap 
Komitmen Organisasi.

\section{Coefficients $^{\mathbf{a}}$}

\begin{tabular}{|c|c|c|c|c|c|}
\hline \multirow[b]{2}{*}{ Model } & \multicolumn{2}{|c|}{$\begin{array}{c}\text { Unstandardized } \\
\text { Coefficients }\end{array}$} & \multirow{2}{*}{$\begin{array}{c}\text { Standardized } \\
\text { Coefficients } \\
\text { Beta }\end{array}$} & \multirow[b]{2}{*}{$\mathrm{t}$} & \multirow[b]{2}{*}{ Sig. } \\
\hline & B & $\begin{array}{l}\text { Std. } \\
\text { Error }\end{array}$ & & & \\
\hline 1 (Constant) & & 0,241 & & 3,521 & 0,001 \\
\hline $\begin{array}{l}\text { Kepuasan } \\
\text { Kerja }\end{array}$ & & 0,061 & 0,710 & 10,855 & 0,000 \\
\hline
\end{tabular}

a. Dependent Variable: Komitmen Organisasi

3. Hipotesis ketiga diuji menggunakan uji analisis regresi berganda dengan alat bantu SPSS. Hasil uji analisis regresi berganda adalah sebagai berikut:

\begin{tabular}{|c|c|c|c|c|}
\hline \multicolumn{5}{|c|}{ Model Summary } \\
\hline & & & Adjusted R & Std. Error of the \\
\hline Model & $\mathrm{R}$ & R Square & Square & Estimate \\
\hline 1 &, $721^{\mathrm{a}}$ &, 519 &, 511 & ,30568 \\
\hline
\end{tabular}

a. Predictors: (Constant), Kepuasan Kerja, Efikasi Diri

Variabel Efikasi diri dan Kepuasan kerja secara simultan (bersama-sama) berpengaruh positif terhadap variabel Komitmen organisasi. Nilai $\mathrm{R}$ square 0,519 atau sama dengan $51,9 \%$ angka tersebut mengandung arti bahwa variabel Efikasi diri $\left(\mathrm{X}_{1}\right)$ dan variabel Kepuasan kerja $\left(\mathrm{X}_{2}\right)$ secara simultan (bersama-sama) berpengaruh terhadap variabel Komitmen organisasi (Y) sebsar 51,9\%. Sedangkan sisanya $(100 \%-51,9 \%=48,1 \%)$ dipengaruhi oleh variabel lain di luar persamaan regresi ini atau variabel yang tidak diteliti.

\begin{tabular}{|c|c|c|c|c|c|c|}
\hline \multicolumn{7}{|c|}{ Anova ${ }^{a}$} \\
\hline \multicolumn{2}{|c|}{ Model } & $\begin{array}{l}\text { Sum of } \\
\text { Squares }\end{array}$ & df & Mean Square & $\mathrm{F}$ & Sig. \\
\hline \multirow[t]{3}{*}{1} & Regression & 11,616 & 2 & 5,808 & 62,157 &, $000^{\mathrm{b}}$ \\
\hline & Residual & 10,745 & 115 & ,093 & & \\
\hline & Total & 22,361 & 117 & & & \\
\hline
\end{tabular}

a. Dependent Variable: Komitmen Organisasi

b. Predictors: (Constant), Kepuasan Kerja, Efikasi Diri

Berdasarkan table Output (Anova) diketahui bahwa nilai signifikan (Sig.) dalam uji F sebesar 0,000. Karena Sig. $0,000<0,05$ dan nilai F hitung 62,157 >Ftabel 3,92 maka sebagaimana dasar dalam pengambilan keputusan dalam uji $\mathrm{F}$, maka dapat disimpulkan bahwa Efikasi diri $\left(\mathrm{X}_{1}\right)$ dan Kepuasan kerja $\left(\mathrm{X}_{2}\right)$ secara simultan 
(bersama-sama) berpengaruh terhadap Komitmen organisasi (Y) atau berarti signifikan.

Dengan demikian, maka persyaratan agar kita dapat memaknai nilai koefisien determinasi dalam analisis regresi linier berganda sudah terpenuhi.

\begin{tabular}{|c|c|c|c|c|c|c|}
\hline \multicolumn{7}{|c|}{ Coefficients $^{\mathrm{a}}$} \\
\hline & & \multirow{2}{*}{\multicolumn{2}{|c|}{ Unstandardized Coefficients }} & \multirow{3}{*}{$\begin{array}{c}\text { Standardized } \\
\text { Coefficients } \\
\text { Beta }\end{array}$} & \multirow[b]{3}{*}{$\mathrm{t}$} & \multirow[b]{3}{*}{ Sig. } \\
\hline & & & & & & \\
\hline \multicolumn{2}{|c|}{ Model } & B & Std. Error & & & \\
\hline \multirow[t]{3}{*}{1} & (Constant) & 1,159 &, 288 & & 4,031 &, 000 \\
\hline & Efikasi Diri &,- 166 & ,086 &,- 159 & $-1,929$ &, 056 \\
\hline & Kepuasan Kerja & ,760 & ,078 &, 809 & 9,792 & 000 \\
\hline
\end{tabular}

a. Dependent Variable: Komitmen Organisasi

Tabel Coefficients memberikan informasi tentang persamaan regresi dalam penelitian ini. Persamaan regresi pengaruh variabel Efikasi diri dan

Kepuasan kerja terhadap Komitmen organisasi adalah

$$
\mathrm{Y}=1,159-0,166+0,760
$$

\section{F. KESIMPULAN, IMPLIKASI DAN SARAN}

\section{Kesimpulan}

Penelitian ini berhasil membuktikan bahwa ada pengaruh efikasi diri dan kepuasan kerja secara sendiri sendiri atau secara bersama sama terhadap komitmen organisasi. Hasil penelitian ini memperkaya bukti empiris bahwa jika guru mempunyai efikasi diri yang tinggi dan merasa puas terhadap pekerjaannya maka guru tersebut juga lebih betkomitmen terhadap organisasinya. Keyakinan diri guru yang tinggi menyebabkan guru tersebut dapat menyelesaikan tugas,persoalan,dan permasalahan yang ada di dalam sekolah dan ini mengakibatkan guru tersebut juga berkomitmen terhadap organisasinya. Kepuasan yang menimbulkan perasaan senang akhirnya juga akan meningkatkan komitmen guru tersebut pada organisasinya.

\section{Keterbatasan Penelitian}

Penelitian ini hanya meneliti Efikasi diri dan Kepuasan kerja serta Komitmen organisasi guru secara umum. Penulis tidak meneliti berdasarkan umur, jenis kelamin dan lama masa kerja. Oleh karena itu untuk mengoptimalkan hasil penelitian, criteria tersebut juga dapat digunakan.

Penelitian ini melibatkan subjek penelitian dalam jumlah terbatas, 
Pengaruh Efikasi Diri dan Kepuasan Kerja Guru terhadap Komitmen Organisasi SPK SD dan SMP di Kecamatan Cengkareng dan Kalideres, Jakarta.

sehingga hasilnya belum dapat digeneralisasikan pada kelompok subjek dengan jumlah besar.

\section{Saran}

Peneliti mendatang dapat menguji pengaruh efikasi diri dan kepuasan kerja terhadap komitmen organisasi dengan berdasarkan umur,jenis kelamin,dan lama masa kerja.

\section{DAFTAR PUSTAKA}

Arifin,Muhamad., Putro, Setiadi Cahyono., Putranto,Hari.(2014).Hubungan kemampuan efikasi diri dan kemampuan kependidikan dengan kesiapan menjadi guru TIK mahasiswa pendidikan teknik informatika. Teknologi dan Kejuruan, Vol 37,No.2, 129-136.

Arslan,Ali.(2019). The mediating role of prospective teachers' teaching self efficacy between self efficacy sources and attitude towards teaching profession. International Journal of Educational Methodology,5(1),87-96,doi:10.12973/ijem.5.1.101

Arta, Deddy Novie Citra. (2014).Pengaruh kepuasan kompensasi dan lingkungan kerja terhadap motivasi serta dampaknya pada kepuasan kerja karyawan perusahaan daerah air minum kabupaten Bantul Daerah Istimewa Yogyakarta. Jurnal Business :Teori dan Implementasi, Vol 5,No.2, 182-205.

Baluyos,Genelyn.B.,Rivera,Helen.L.,Baluyos,Esther.L.(2019).Teachers,job satisfaction and work performance.Open Journal of Social Sciences,7,206-221. Bandura,Albert, 1997. Self efficacy- the exercise of control. USA: W.H. Freeman and Company.

Bowles,Freddie A., Pearman, Cathy J,2017.Self -Efficacy in Action.USA: Rowman\& Littlefield.

Cicik Susana.,Eka Askafi.,\&Aris Syahidin.(2017).Pengaruh kepemimpinan transformational dan motivasi berprestasi terhadap komitmen organisasional guru di SMPN 1 Selopuro kabupaten Blitar. Jurnal Ilmiah Ilmu Ilmu Ekonomi,Vol10,No.2,1-11.

Colquitt, J.A \& et.al, (2015). Organizational Behavior; Improving Performance and Commitmentin the Wrkplace, $4^{\text {th }}$ Ed. Mc. Graw-Hill Education.

Dwiutami, Lussy., \& Wardi, Tantri Dwinantika.(2015). Efikasi diri dan kemampuan literasi informasi pada guru Sekolah Menengah Atas. Jurnal Penelitian dan Pengukuran Psikologi Volume 4,Nomor 2, 65-73

Ghufron,M. Nur.,S,Rini Risnawita, 2014. Gaya Belajar (edisi II). Yogyakarta: Pustaka Pelajar.

Gibson, James L.,et.al, 2009. Organizations Behavior,Structure, Process (thirteenth edition). Singapore : Mc Graw Hill Higher Education

Harun Samsuddin.,2018. Kinerja Karyawan tinjauan dari simensi gaya kepemimpinan,budaya organisasi dan komitmen organisasi( edisi I),Sidoarjo: 
Indomedia Pustaka.

Ilahi,Dede Kurnia.,Mukzam, Mochamad Djudi., Prasetya, Arik. (2017). Pengaruh kepuasan kerja terhadap disiplin kerja dan komitmen organisasi. Jurnal Administrasi Pendidikan, Vol 44,No,1, 31-39.

J.Winardi.,2015. Manajemen Perilaku Organisasi (edisi revisi),Jakarta: Prenafamedia Group.

Jamal,Sajid, 2013. Organizational Commitment Among School Teachers. USA: LaMBERT Academic Publishing.

Jumari ., Yudana ., \& Sunu. ( 2013). Pengaruh budaya organisasi,efikasi diri dan kepuasan kerja terhadap kinerja mengajar guru SMK Negeri kecamatan Denpasar Selatan. Journal Program Pasca sarjana Universitas Pendidikan Ganesha Program Studi Administrasi Pendidikan, Volume 4.

K.Nigama.,S.Selvabaskar.,S.T.Surulivel.,R.Alamelu.,Ms.D.Uthaya

Joice.(2018).Job satisfaction among school teachers. International Journal of Pure and Applied Mathematics, Vol119,No.7,2645-2655.

Kaswan.,2018. PerilakunOrganisasi Positif (edisi 1 ). Bandung : C.V. Pustaka Setia.

Kembau, Jefan Basten., Sendow,Greis.M.,Tawas, Hendra.N.(2018).Pengaruh keterlibatan kerja dan kompetensi kerja terhadap kepuasan kerja dan kinerja guru Sekolah Dasar di kecamatan Malalayang kota Manado. Jurnal EMBA, Vol 4,3428-3437.

Khayati, Nur ., \& Sarjana, Sri (2015). Efikasi diri dan kreativitas menciptakan inovasi guru. Jurnal Pendidikan dan Kebudayaan, Volume 21 Nomor 3, 243-261.

Kumala,Ismaya Priska.,Burhanuddin.,\& Bafadal, Ibrahim.(2018). Hubungan antara kepuasan kerja,kompetensi,dan kinerja guru.Jurnal Administrasi dan Manajemen Pendidikan, Vol 1,Nomor 4,400-409.

Kusuma,Budi Hartono.,Lina.(2018).Pengaruh kepuasan karyawan terhadap kinerja karyawan dengan komitemen organisasi sebagai variabel interviewing.Jurnal Manajemen Maranatha, Vol 17,No.2,127-134.

Kusumawati,Paramitha., Cahyani, Berliana Henu.(2013).Peran efikasi diri terhadap regulasi diri pada pelajaran matematika ditinjau dari jenis kelamin.Jurnal SPIRITS, Vol 4 ,No.1,54-63.

Luthans,Fred,2006. Perilaku Organisasi( edisi sepuluh). Yogyakarta: P.T. Andi.

Mahler,Daniela.,Grobschedi,Jorg.,Harms,Ute. (2017). Opportunities to learn for teachers' self efficacy and enthusiasm. Hindawi Education Research International, Vol 2017,Article ID 4698371,17 pages,https://doi.org/10.1155/2017/4698371.

Manery,Benyamin Richard.,Lengkong, Victor P.K.,Saeranh, Regina T. (2018).Pengaruh komitmen organisasi dan budaya organisasi terhadap kinerja pegawai di BKDPSDA di kabupaten Halmahera Utara. Jurnal EMBA,Vol 6,No.4,1968-1977.

Megawanti,Priarti. (2015).Hubungan budaya organisasi dan kepuasan kerja dengan komitmen organisasi guru honoreer.Jurnal Formatif,Vol3,No.1, 26-38. 
Monika., Adman. (2017). Peran efikasi diri dan motivasi belajar dalam meningkatkan hasil belajar siswa sekolah menengah kejuruan. Jurnal Pendidkan Manajemen Perkantoran, Vol 2 No 2,219-226.

Nartey,Laud Teye 2018. Organizational Support,Teachers' Job Satisfaction and Commitment. USA: LAP Lambert Academic Publishing.

Necmi Gokyer.(2018).Organizational commitment of high school teachers.Journal of Education and Training Studies, Vol6,No.3a,115-125.

Nelda,Fitri. (2016). Hubungan kepemimpinan kepala sekolah dengan komitmen guru dalam melaksanakan tugas di SMK 2 Pariaman.Jurnal Adminitrasi Pendidikan, Vol 1,No.29, 1-8.

Ningsih,Prapti.(2016).Pengaruh komitmen,kompetensi,dan lingkungan kerja terhadap kinerja guru di kecamatan Pasangkayu kabupaten Mamuju Utara. e Jurnal Katalogis, Vol 4,No.11,127-137.

Noermijati, 2013. Kajian Tentang Aktualisasi Teori herzberg ,Kepuasan Kerja dan Kinerja Spiritual Manajer Operasional (edisi I). Malang: UB Press.

Pandu Djati Sentano.,Sugih Arijanto.,\& Yoanita Yuniati.(2016).Peningkatan kepuasan kerja dan employee engagement pengajarvdan karyawan di yayasan pendidikan"x" Bandung. Jurnal Online Institut Teknologi Nasional,Vol 4,No.1,74-86.

Peretomode,Victor.F.,Bello,Stella.O.(2018).Analysis of teachers'commitment and dimensions of organizational commitment in Edo State Public Secondary Schools.Journal of Educational and Social Research,Vol 8, No.3,87-92.

Porter, LW., Steers, RH, Mowday, R., \& Boulian, P. (1974.Organizational commitment, job satisfaction, turnover among psychiatric technicians. Journal of applied psycologhy, 59,604.

Putri, Intan Agitha., Astuti, Yulianti Dwi.(2018).Hubungan antara efikasi diri dan kecenderungan kambuh pada pecansu narkoba yang menjalani rehabilitasi di Yogyakarta. Psikologika:Jurnal Pemikiran dan Penelitian Psikologi, Volume 23 Nomor 2,151-164.

Putri,Renata Melati ., \& Priambodo, Anung. (2015). Pengaruh efikasi diri,penetapan tujuan dan kepuasan kerja pada pengembangan kompetensi guru pendidikan jasmani,olah raga dan kesehatan (studi pada guru pendidikan jasmani,olahraga dan kesehatan di SMA Negeri Surabaya. Jurnal Pendidikan Olahraga dan Kesehatan ,Volume 03 Nomor 1, 220-226.

Raj,Lipin.,Dr Josheena Jose.(2019). A study on the job satisfaction and institutional commitment among school teachers in Kerala with special reference to Malappuram District. International Journal in Management and Social Science, Vol07,Issue 03,62-74.

Ratnawati.,Mariyudi.,Teuku Zulkarnaen.(2018). Pengaruh self efficacy dan locus of control terhadap kinerja guru sekolah Sukma Bangsabdengan kepuasan kerja sebagai variabel interviewing. Jurnal Manajemen Indonesia, Vol 3,No.2, 40-51.

Robbins, Stephen P. 1999. Prinsip-prinsip perilaku organisasi. Edisi ke 5. Jakarta: Erlangga. 
Salimah.,Ceacilia Sri Mindarti.(2017).Pengaruh kompetensi kepribadian dan efikasi diri guru terhadap kinerja gurunyang dimediasi oleh komitmen organisasional. Jurnal Telaah Manajemen, Vol 14,edisi 1,119-126.

Santrock,John W,2007. Child Development (eleventh edition). USA: Mc Graw Hill

Saragi,Ahmad Syafli. (2014).Pengaruh budaya sekolah,kepuasan kerja,dan motivasi kerja terhadap kinerja guru SMA Negeri di kota Binjai.Jurnal Pendidikan dan Kepengawasan, Vol 2,No.2, 33-49.

Sari, Dewi Purnama.(2018). Pengaruh lingkungan kerja dan disiplin kerja terhadap kepuasan kerja guru Sekolah Menengah Kejuruan swasta se kecamatan Pondol Aren. Jurnal Saintika UNPAM,vol 1,No.1,108-132.

Sihotang, H. (2016). The Effect of Certicication and Self-Concept on The Lecturers Performance of private Higher Education at Kopertis Wilayah III Jakarta.

Sokmen, Yavuz.,Killic,Durmus.(2019).The relationship between primary school teachers' self efficacy,autonomy,job satisfaction,teacher engagement and burnout: a model development study.International Journal of Research in Education and Science, Vol5,Issue 2,709-721.

Sopiah,2018. Perilaku Organisasional ( edisi I). Yogyakarta. ANDI.

Steers, R.M., \& Porter, L.W. 1983. Motivation and work behavior. Third edition. New York: Mc. Graw Hill Book Company.

Stephen P. Robbins, 1996. Perilaku organisasi, konsep, kotroversi dan aplikasi. Alih bahasa: Hadyana Pujaatmaka. Edisi ke 6 Penerbit PT Bhuana Ilmu Populer Jakarta.

Sugiyono, 2018. Metode Penelitian Kuantitatif (edisi I). Bandung: Alfabeta.

Suryaman. (2018).Model peningkatan komitmen organisasi pada perguruan tinggi swasta kota dan kabupaten Serang untuk meningkatkan kinerja organisasasi secara berkelanjutan.Jurnal Manajemen, Vol 8,No.2,102-115.

Tabancali,Erkan.(2016). The relationship between teachers' job satisfaction and loneliness at the workplace. Eurasian Journal of Education Research, Issue 66,263-280.

Tadesse,Endale Fantahun.(2019).Teachers ' organizational commitment at secondary school in Addis Ababa,Ethiopia. International Journal of Education and Research,Vol7,No.4, 53-68.

Tentama, Fatwa.,\& Pranungsari, Dessy.(2016). The roles of teachers' work motivation and teachers' job satisfaction in teh organizational commitment in extraordinary schools. International Journal of Evaluation and Research in Education, Vol 5,No.1. 39-45.

Tezer,Murat.,Kan,Sebnem Guldal.,Bas,Cizem.(2019). Determinations of multi dimensional self efficacybbeliefs of prospective teachers towards creative drama activities.International Journal of Instruction, Vol12,No.1,783-796.

Wasahua,Melda. ( 2018). Analysis pengaruh kompetensi,komitmen,dan motivasi terhadap kinerja dosen perguruan tinggi swasta kopertisnwilayah XII Maluku dan 
Pengaruh Efikasi Diri dan Kepuasan Kerja Guru terhadap Komitmen Organisasi SPK SD dan SMP di Kecamatan Cengkareng dan Kalideres, Jakarta.

Maluku Utara di kota Ambon.Jurnal SOSOQ,Vol6,No.2,122-136.

Werang, Basilius Redan., Agung, Anak Agung Gede. (2017).Teachers' job satisfaction,organizational commitment,and performance in Indonesia:a study from Merauke District,Papua. Intetnational Journal of Development and Sustainability, Vol 6,Number 8,700-711.

Yusnita,Maya.(2015).Pengaruh masa kerja dan kepuasan kerja terhadap komitmen organisasi guru honor .Holistic Hournal of Management Research,Vol 3,No.2,65-78.

Zacharo,Kouni.,Marios, Koutsoukos .,Dimitra,Panta.(2018).Connection of teachers'organizational commitment and transformational leadership.a case study from Greece.International Journal of Learning ,Teaching, and Educational Research,Vol 17,No.8, 89-106. 